九州大学学術情報リポジトリ

Kyushu University Institutional Repository

\title{
Simulating Daily Runoff in Hydrologic Standard Basin Considering Agricultural Reservoir Operation
}

$\mathrm{NOH}$, Jaekyoung

Department of Agricultural and Rural Engineering, College of Agriculture and Life science, Chungnam National University | Science for Bioproduction Environment, Faculty of Agriculture, Kyushu University

\section{LEE, Jaenam}

Rural Research Institute, KRC

SHINOGI, Yoshiyuki

Science for Bioproduction Environment, Faculty of Agriculture, Kyushu University

$\mathrm{OH}$, Taek-Keun

Department of Bio-Environmental Chemistry, College of Agriculture and Life science, Chungnam National University

https://doi.org/10.5109/1911210

出版情報：九州大学大学院農学研究院紀要. 63 (1)，pp.119-130，2018-02-27. Faculty of Agriculture, Kyushu University

バージョン :

権利関係 : 


\title{
Simulating Daily Runoff in Hydrologic Standard Basin Considering Agricultural Reservoir Operation
}

\author{
Jaekyoung NOH${ }^{1}$, JaenamLEE ${ }^{2 *}$, Yoshiyuki SHINOGI ${ }^{3}$ and Taek-Keun $\mathrm{OH}^{4 *}$ \\ Science for Bioproduction Environment, Faculty of Agriculture, Kyushu University, \\ Hakozaki 6-10-1, Higashi-ku, Fukuoka city 812-8581, Japan \\ (Received October 28, 2017 and accepted November 20, 2017)
}

\begin{abstract}
The amounts of streamlow in the downstream are influenced from the operation of agricultural reservoirs upstream. To simulate daily streamflow by considering the operation of irrigation reservoirs upstream located in the standard basins, a system was constructed to simulate the amount of streamflow in order from upstream to downstream standard basins. The DAWAST model was selected to daily hydrologic runoff model, and daily reservoir water balance model was constructed. These two basic models were coupled to the system to simulate the downstream streamflow amount by considering the operation of reservoirs upstream. The Gemho river basin with watershed area of $2,092 \mathrm{~km}^{2}$ was selected to study basin, in which this basin was separated to 20 standard basins and has 21 reservoirs with total water storage above $1 \mathrm{Mm}^{3}$. Using the system with runoff and reservoir water balance modules, daily streamflows at each junction were simulated and compared with each other in cases of considering and no considering upstream reservoir operations. And using the above daily simulated streamflows, flow duration curves were drawn and compared with each other. The streamflow amounts of standard basins considering reservoir operations were shown to less than those of no considering reservoir operations in case of agricultural reservoir with low storage capacity. But the Youngcheon dam with high water storage capacity of $81 \mathrm{Mm}^{3}$ had a great influence on the downstream stream flow amount according to reservoir operation. The daily runoff modeling of considering upstream reservoir operation resulted more accurately than those of no considering reservoir operation.
\end{abstract}

Key words: agricultural reservoir, daily runoff, flow duration

\section{INTRODUCTION}

The operation of upstream dams and reservoirs in the riverbasin has a significant impact on the downstream flow in time. Factors affecting river flow vary not only with the existence of dams and reservoirs but also with reservoir connections, sewage treatment reuse, adjustment of water rights, and with water transfer to other watershed (MOLIT, 2009; Choi, 2010; Ko, 2015). Hydraulic structures in Korea are divided into multipurpose dams, domestic and industrial water dams, hydroelectric dams, and agricultural reservoirs depending on the purpose of supplying water. Of these, the number of agricultural reservoirs is the largest with 17,477 sites nationwide, and the number of reservoirs over $300,000 \mathrm{~m}^{3}$ is 1,209, accounting for $7 \%$ (Kim, 2015). Kim et al. (2002) analyzed the change of flow durations

1 Department of Agricultural and Rural Engineering, College of Agriculture and Life science, Chungnam National University, Daejeon 305-764, Korea

2 Rural Research Institute, KRC, Ansan, Gyeonggi-do,15634, Korea

3 Science for Bioproduction Environment, Faculty of Agriculture, Kyushu University, Hakozaki 6-10-1, Higashi-ku, Fukuoka city 812-8581, Japan

${ }^{4}$ Department of Bio-Environmental Chemistry, College of Agriculture and Life science, Chungnam National University, Daejeon 305-764, Korea

These two authors contributed equally to this work and should be considered co-corresponding authors

* Corresponding author (E-mail: melody_jn@naver.com) (J. LEE)

* Corresponding author (E-mail: ok5382@cnu.ac.kr) (T. K. OH) in the dam downstream due to the construction of Daecheong dam, and Lee and Kim (2011) analyzed the change of water resources environment due to dam construction. In addition, Kim and Lee (2009) applied the SWAT model to the Soyanggang dam and Chungju dam, and Yeo (2012) applied the SWAT model to the Chungju dam to compare the changes of river flow with and without operation of the multi-purpose dam. Most of the researches in Korea and abroad have been carried out with a large scale hydraulic structure such as multi-purpose dams (Kim et al., 2002; Kim, 2007; Shin et al., 2007; Mwamila et al., 2008; Wellmeyer et al.). However, some studies on agricultural reservoirs are limited to some reservoirs in the watershed (Jee et al., 2012; Lee and Noh, 2015). It is necessary to determine the impact of agricultural reservoirs on the overall watershed flow for reasonable water resources planning.

Agricultural reservoirs are located in the upstream watersheds nationwide and have a significant impact on the flow of tributary streams. In order to analyze the river flow through an arbitrary boundary point, it is necessary to divide the watershed appropriately for the purpose of analysis considering the reservoir location. The Ministry of Land, Transport and Maritime Affairs has divided the watershed by standardizing the whole country to 21 major regions, 117 central regions, and 840 standard watersheds in order to efficiently implement the national water resources planning and management (http:/ /www. wasis.go.kr).

In the long-term comprehensive plan for water resources (MOCT, 2006), the runoff analysis was carried out by the middle sized regions and the operation of 
agricultural reservoirs and dams was not considered. In order to further study the water resources planning in consideration of tributary streams, it is necessary to consider the operation of agricultural reservoirs and to make reference to the standard hydrologic watershed, which is the minimum watershed unit. As a result of changes in the water environment due to the 4 Rivers Rehabilitation Project, the standard watershed of the water unit map was re-established as Ver. 3.0 (MOLIT, 2010) considering the location of the newly constructed multifunctional weirs and the location of the raised agricultural reservoirs. Therefore, in this study, we considered the operation of the reservoir for the runoff analysis of the standard watershed unit, and constructed a model to quantitatively analyze the flow rate change of the downstream river considering the upstream agricultural reservoirs and dams and to evaluate its usefulness.

\section{MATERIALS AND METHODS}

\section{Study areas}

The study river basin was selected to the Geumho river basin with watershed area of $2,092 \mathrm{~km}^{2}$, which is tributary basin of the Nakdong river with watershed area of $23,702 \mathrm{~km}^{2}$. Land uses of Geumho river basin consist of upland $220.56 \mathrm{~km}^{2}$ (10.5\%), paddy field $382.05 \mathrm{~km}^{2}$ (18.3\%), forest $1,390.46 \mathrm{~km}^{2}(66.5 \%)$, urban area $75.91 \mathrm{~km}^{2}(3.6 \%)$, and water area $21.25 \mathrm{~km}^{2}(1.0 \%)$ as shown in Fig.1.

Geumho river basin has the elevation range from 1,192 meters at the top of mount Palbong to 14.3 meters in the outlet of the Geumho river (reach length $118.4 \mathrm{~km}$ ), which is located in $206 \mathrm{~km}$ from the estuary. Elevation is distributed with $520.85 \mathrm{~km}^{2}$ below $100 \mathrm{~m}$ (24.9\%), $618.54 \mathrm{~km}^{2}$ less than $200 \mathrm{~m} \mathrm{(29.6 \% ),}$ $340.46 \mathrm{~km}^{2}$ less than $300 \mathrm{~m}$ (16.3\%), $239.15 \mathrm{~km}^{2}$ less than $400 \mathrm{~m}$ (11.4\%), $170.26 \mathrm{~km}^{2}$ less than $500 \mathrm{~m}(8.1 \%)$, $102.39 \mathrm{~km}^{2}$ less than $600 \mathrm{~m}(4.9 \%), 54.25 \mathrm{~km}^{2}$ less than $700 \mathrm{~m} \mathrm{(2.6 \% ),} 28.37 \mathrm{~km}^{2}$ less than $800 \mathrm{~m} \mathrm{(1.4 \% ),}$ $12.03 \mathrm{~km}^{2}$ less than $900 \mathrm{~m}(0.6 \%)$, and $6.04 \mathrm{~km}^{2}$ over $900 \mathrm{~m}(0.3 \%)$ as shown in Fig. 2.

There are 18 agricultural reservoirs and 2 domestic dams, and one multipurposed dams with effective water storage over $1 \mathrm{Mm}^{3}$ within the Geumho river basin as

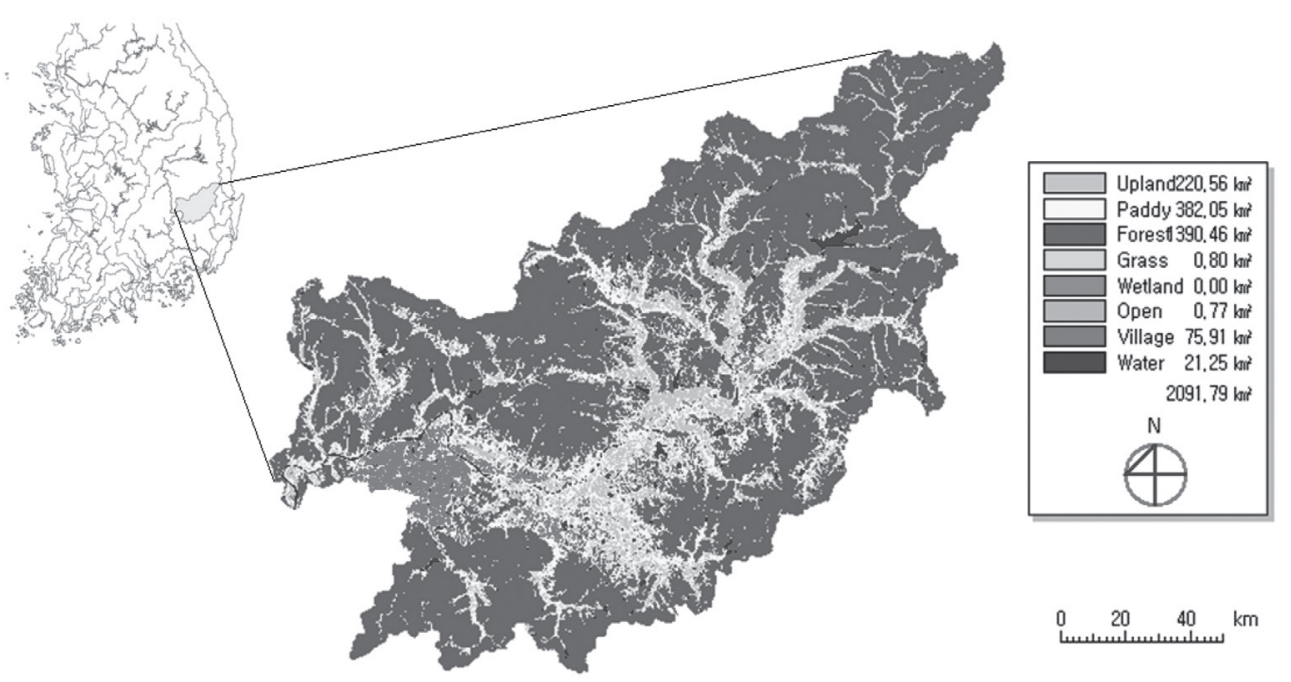

Fig. 1. Location and land uses of Geumho river watershed.

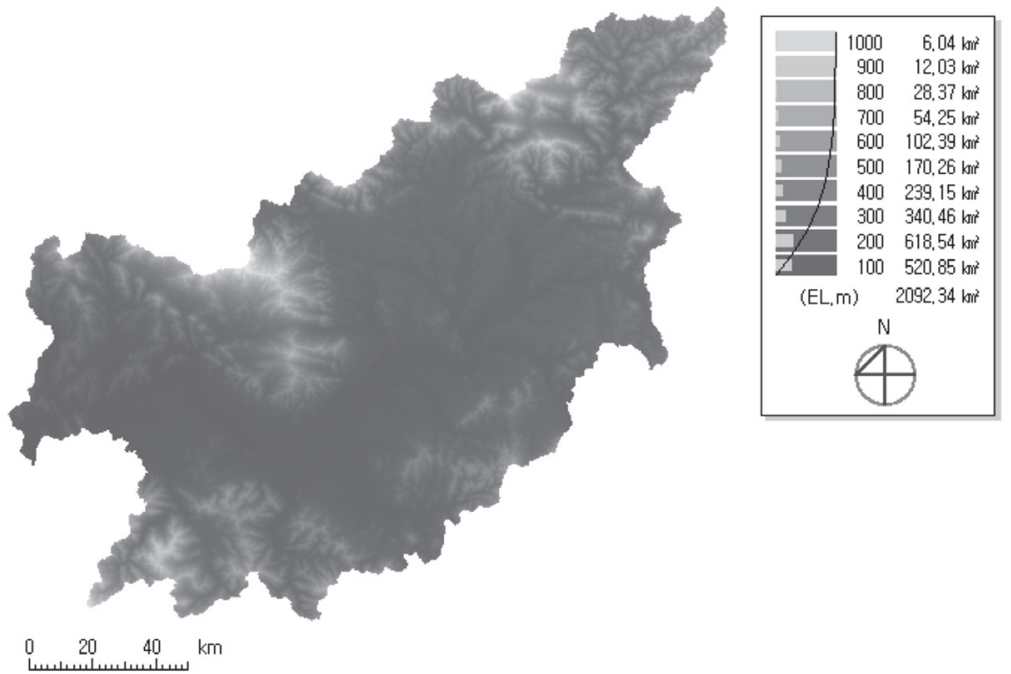

Fig. 2. DEM of Geumho river watershed. 
shown in Fig. 3 and Table 1.

The study flow and content include selection of river basin, separation of standard hydrologic basin, data collection, modeling at stream network considering upstream reservoir operation, and comparison of streamflows in cases with and without upstream reservoirs as shown in Fig. 4.

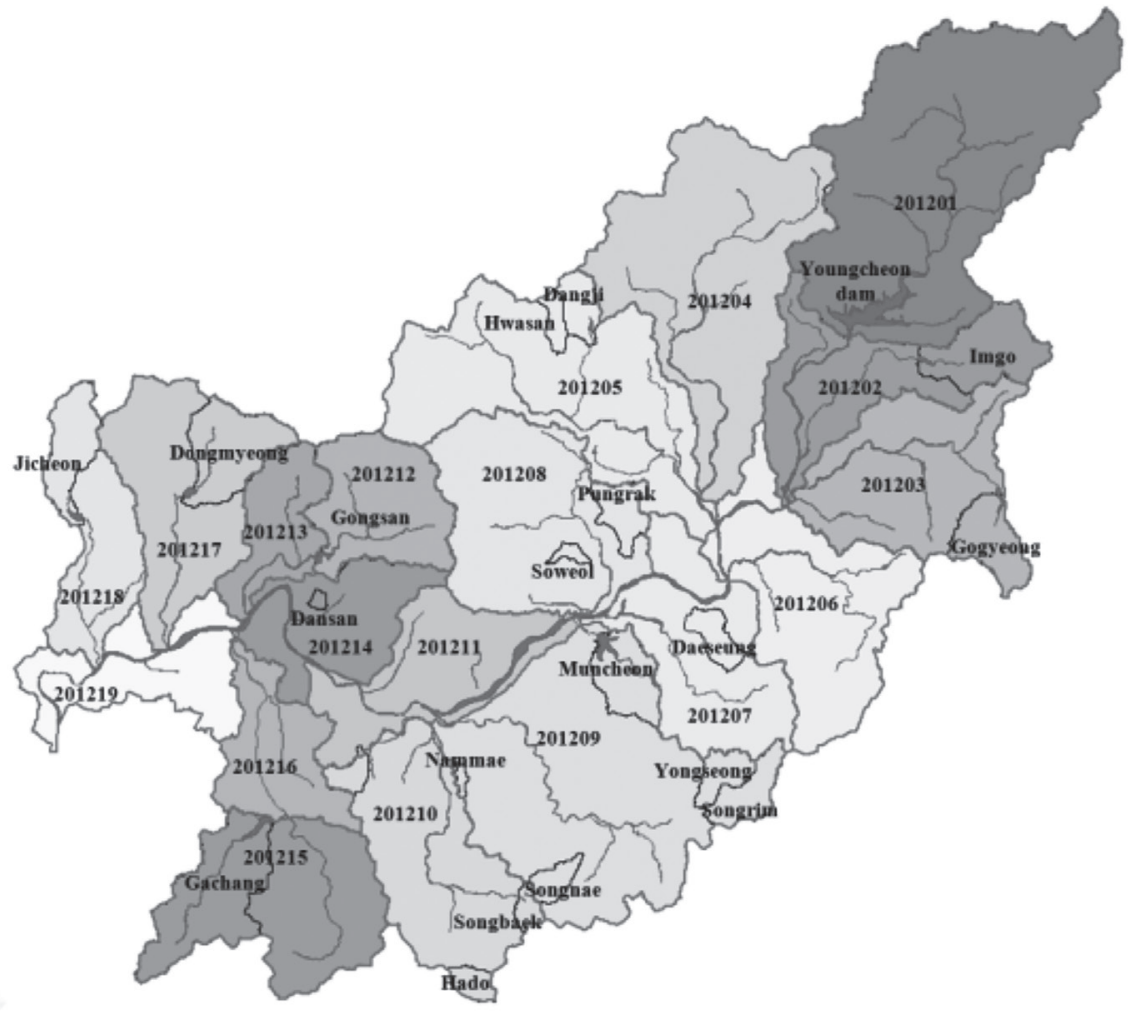

Fig. 3. Separation of standard watershed and location of reservoir and dam within Geumho river watershed.

Table 1. Characteristics reservoirs and dams over $1 \mathrm{Mm}^{3}$ within Geumho riverbasin

\begin{tabular}{|c|c|c|c|c|}
\hline Reservoir name & $\begin{array}{c}\text { Watershed area } \\
\left(\mathrm{km}^{2}\right)\end{array}$ & $\begin{array}{c}\text { Effective water storage } \\
\left(10^{3} \mathrm{~m}^{3}\right)\end{array}$ & $\begin{array}{c}\text { Irrigated area } \\
\text { (ha) }\end{array}$ & Remark \\
\hline Total & 587.03 & $120,952.6$ & 4,103 & \\
\hline Youngcheon dam & 235 & 81,400 & - & $\mathrm{IW}^{\mathrm{a})}: 400,000 \mathrm{~m}^{3} / \mathrm{d}$ \\
\hline Imgo & 26.84 & 1,515 & 206 & \\
\hline Gogyeong & 13.45 & $1,345.5$ & 215 & \\
\hline Hwasan & 3.95 & $1,009.2$ & 117 & \\
\hline Dangju & 8.4 & 1,028 & 115 & \\
\hline Pungrak & 9.8 & $2,143.1$ & 235 & \\
\hline Daeseung & 7.15 & 1,619 & 190 & \\
\hline Soweol & 15.17 & $2,066.3$ & 155 & \\
\hline Muncheon & 25.33 & $2,533.2$ & 1900 & \\
\hline Songrim & 11.53 & 1,199 & 183 & \\
\hline Yongseong & 7.38 & 1,943 & 47 & \\
\hline Songnae & 5.3 & 1,087 & 47 & \\
\hline Hado & 4.55 & 1,199 & 52 & \\
\hline Songbaek & 3.45 & 1,463 & 124 & \\
\hline Nammae & 0.8 & 1,120 & 100 & \\
\hline Dansan & 60.88 & 2,253 & 59 & \\
\hline Gongsan & 60.3 & 4,500 & - & $\mathrm{DW}^{\mathrm{b}}: 40000 \mathrm{~m}^{3} / \mathrm{d}$ \\
\hline Gachang & 43 & 8,100 & - & DW: $60000 \mathrm{~m}^{3} / \mathrm{d}$ \\
\hline Dongmyeong & 26.6 & $1,451.3$ & 82 & \\
\hline Jicheon & 18.15 & 1,978 & 276 & \\
\hline
\end{tabular}

a) IW means industrial water supplied to Pohang area.

${ }^{b} \mathrm{DW}$ means domestic water supplied to Daegu city. 
Table 2. Watershed area, population, and industry works by sub-watershed within Geumho river basin

\begin{tabular}{|c|c|c|c|c|}
\hline \multirow{2}{*}{ Juction No. } & \multicolumn{2}{|c|}{ Sub-watershed } & \multirow{2}{*}{ Population } & \multirow{2}{*}{ Industry works } \\
\hline & Name & Area $\left(\mathrm{km}^{2}\right)$ & & \\
\hline \multirow{3}{*}{ J01 } & Youngcheon & 234.15 & 3,055 & 1,026 \\
\hline & Imgo & 25.84 & 1,313 & 441 \\
\hline & J01-Youncheon-Imgo & 63.33 & 3,553 & 1,194 \\
\hline \multirow{2}{*}{ J02 } & Gogyeong & 16.99 & 996 & 335 \\
\hline & J02-Gogyeong & 100.71 & 17,007 & 5,714 \\
\hline \multirow{3}{*}{ J03 } & Hwasan & 3.89 & 229 & 77 \\
\hline & Dangji & 8.35 & 597 & 201 \\
\hline & J03-Hwasan-Dangji & 83.63 & 5,102 & 1,714 \\
\hline J04 & J04 & 365.32 & 56,997 & 19,151 \\
\hline \multirow{2}{*}{ J05 } & Pungrak & 9.80 & 754 & 253 \\
\hline & J05-Pungrak & 15.33 & 3,681 & 1,237 \\
\hline \multirow{2}{*}{ J06 } & Daeseung & 7.00 & 1,744 & 586 \\
\hline & J06-Daeseung & 58.56 & 5,904 & 449 \\
\hline \multirow{2}{*}{ J07 } & Soweol & 1.82 & 303 & 23 \\
\hline & J07-Soweol & 109.82 & 24,658 & 1,874 \\
\hline \multirow{2}{*}{ J08 } & Muncheon & 15.96 & 11,814 & 898 \\
\hline & J08-Muncheon & 34.44 & 24,467 & 1,859 \\
\hline \multirow{3}{*}{ J09 } & Yongseong & 7.53 & 366 & 28 \\
\hline & Songrim & 11.23 & 545 & 41 \\
\hline & J09-Yongseong-Songrim & 26.82 & 1,325 & 100 \\
\hline \multirow{2}{*}{ J10 } & Songnae & 4.93 & 550 & 42 \\
\hline & J10-Songnae & 81.19 & 32,007 & 2,433 \\
\hline J11 & J11 & 67.54 & 80,407 & 6,111 \\
\hline \multirow{3}{*}{ J12 } & Hado & 4.35 & 235 & 18 \\
\hline & Songbaek & 3.40 & 184 & 14 \\
\hline & J12-Hado-Songbaek & 69.62 & 30,443 & 2,313 \\
\hline \multirow{2}{*}{ J13 } & Nammae & 1.07 & 2,617 & 199 \\
\hline & J13-Nammae & 36.06 & 163,154 & 12,400 \\
\hline J14 & J14 & 1.45 & 2,742 & 99 \\
\hline J15 & J15 & 68.27 & 228,530 & 8,227 \\
\hline \multirow{2}{*}{ J16 } & Dansan & 0.97 & 1,829 & 66 \\
\hline & J16-Dansan & 25.82 & 48,693 & 1,753 \\
\hline \multirow{2}{*}{ J17 } & Gongsan & 58.86 & 110,843 & 8,424 \\
\hline & J17-Gongsan & 62.48 & 228,022 & 8,436 \\
\hline \multirow{2}{*}{ J18 } & Gachang & 42.14 & 18,520 & 667 \\
\hline & J18-Gachang & 125.82 & 409,313 & 15,144 \\
\hline \multirow{2}{*}{ J19 } & Dongmyeong & 19.73 & 1,889 & 70 \\
\hline & J19-Dongmyeong & 92.58 & 397,539 & 14,709 \\
\hline \multirow{2}{*}{ J20 } & Jicheon & 17.93 & 1,075 & 40 \\
\hline & J20-Jicheon & 73.41 & 41,362 & 1,530 \\
\hline
\end{tabular}




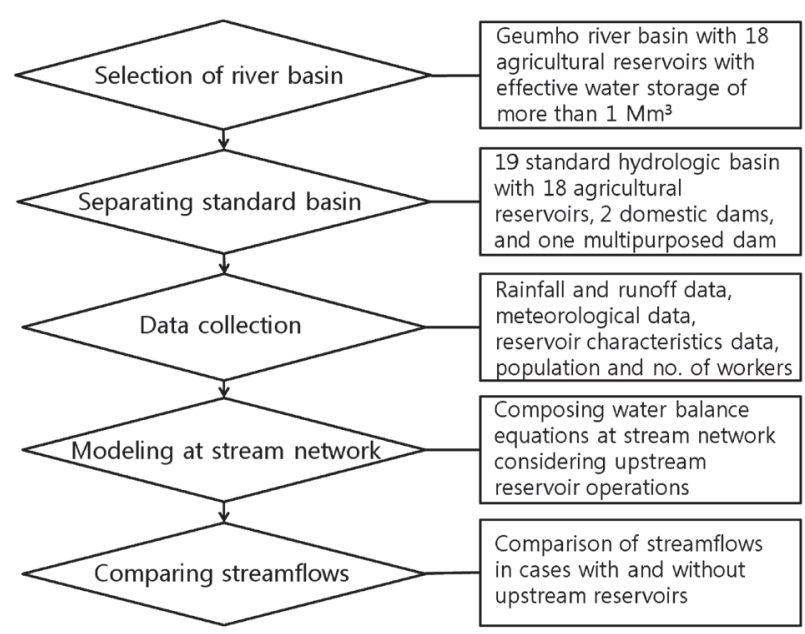

Fig. 4. Study flow an contents.

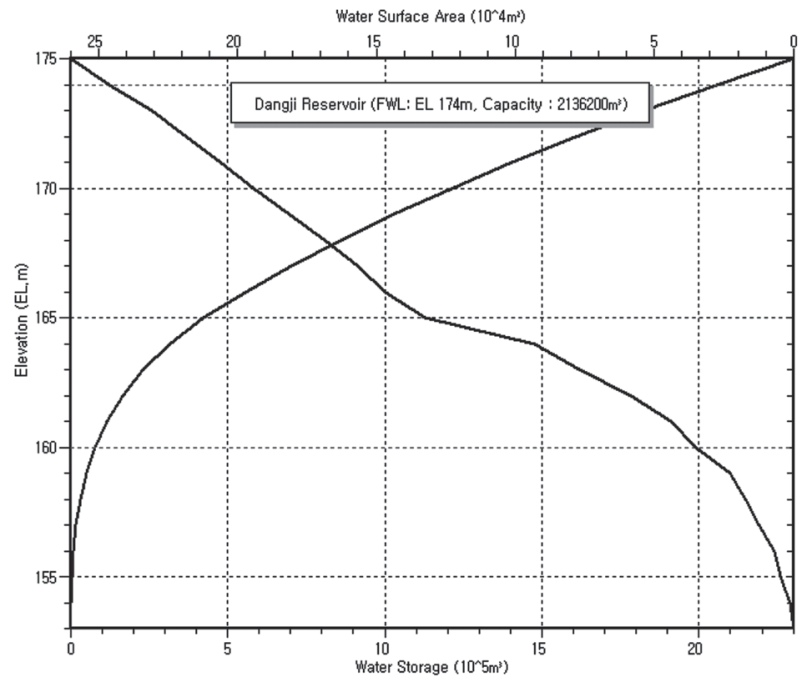

Fig. 5. The example of area capacity curve of Dangji reservoir.

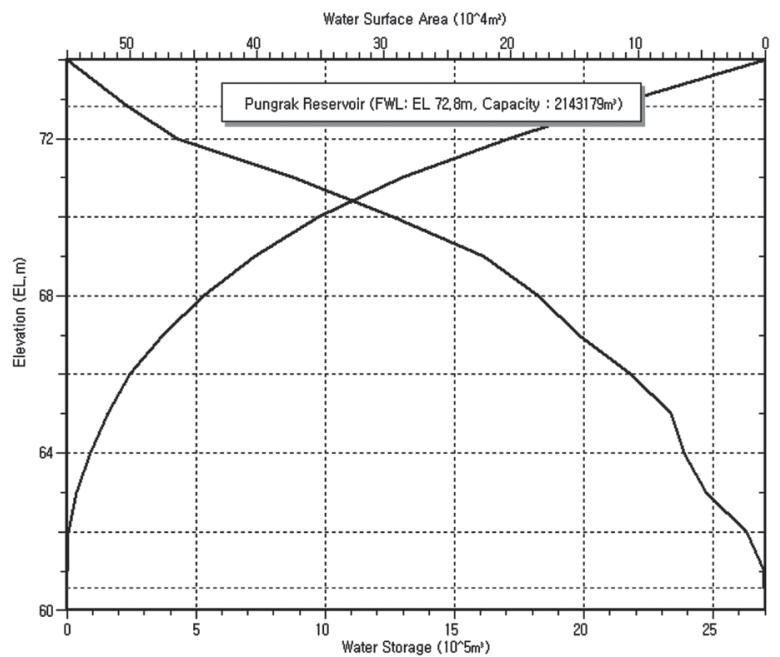

Fig. 6. The example of area capacity curve of Pungrak reservoir.

(QL). The streamflow at the junction J04 in Fig. 7 is the case 8 in Fig. 8 and is simulated as equation (8) in which flow at stream (QS) is consisted of flow from upstream 1 $\left(\mathrm{QS}_{\text {up }}\right)$, flow from upstream $2\left(\mathrm{QS}_{\text {up2 }}\right)$, and lateral flow (QL). The streamflow at the junction J08 in Fig. 7 is the case 7 in Fig. 8 and is simulated as equation (7) in which flow at stream (QS) is consisted of flow from upstream reservoir $\left(\mathrm{SQ}_{\mathrm{up}}\right)$, overflow from upstream reservoir $\left(\mathrm{OV}_{\text {up }}\right)$, flow from upstream $\left(\mathrm{QS}_{\text {up }}\right)$, and lateral flow (QL).

The reservoir water balance equation is composed of reservoir inflow (QI), evaporation at reservoir water surface (EW), and reservoir outflow for water supply (SQ) in which reservoir water storage (S) is added by reservoir inflow (QI), and is reduced by evaporation at reservoir water surface (EW) and reservoir outflow for water supply (SQ).

$$
\begin{aligned}
& \mathrm{QS}_{\text {down }}(\mathrm{i})=\mathrm{SQ}_{\text {up }}(\mathrm{i})+\mathrm{OV}_{\text {up }}(\mathrm{i})+\mathrm{QL}(\mathrm{i}) \\
& \mathrm{QI}_{\text {down }}(\mathrm{i})=\mathrm{SQ}_{\text {up }}(\mathrm{i})+\mathrm{OV}_{\text {up }}(\mathrm{i})+\mathrm{QL}(\mathrm{i})
\end{aligned}
$$




$$
\begin{aligned}
\mathrm{QS}_{\text {down }}(\mathrm{i})= & \mathrm{SQ}_{\text {up }}(\mathrm{i})+\mathrm{QL}(\mathrm{i}) \\
\mathrm{QI}_{\text {down }}(\mathrm{i})= & \mathrm{SQ}_{\text {up }}(\mathrm{i})+\mathrm{QL}(\mathrm{i}) \\
\mathrm{QS}_{\text {down }}(\mathrm{i})= & \mathrm{SQ}_{\text {up1 }}(\mathrm{i})+\mathrm{OV}_{\text {up1 }}(\mathrm{i})+\mathrm{SQ}_{\text {up2 }}(\mathrm{i}) \\
& +\mathrm{OV}_{\text {up } 2}(\mathrm{i})+\mathrm{QL}(\mathrm{i})
\end{aligned}
$$

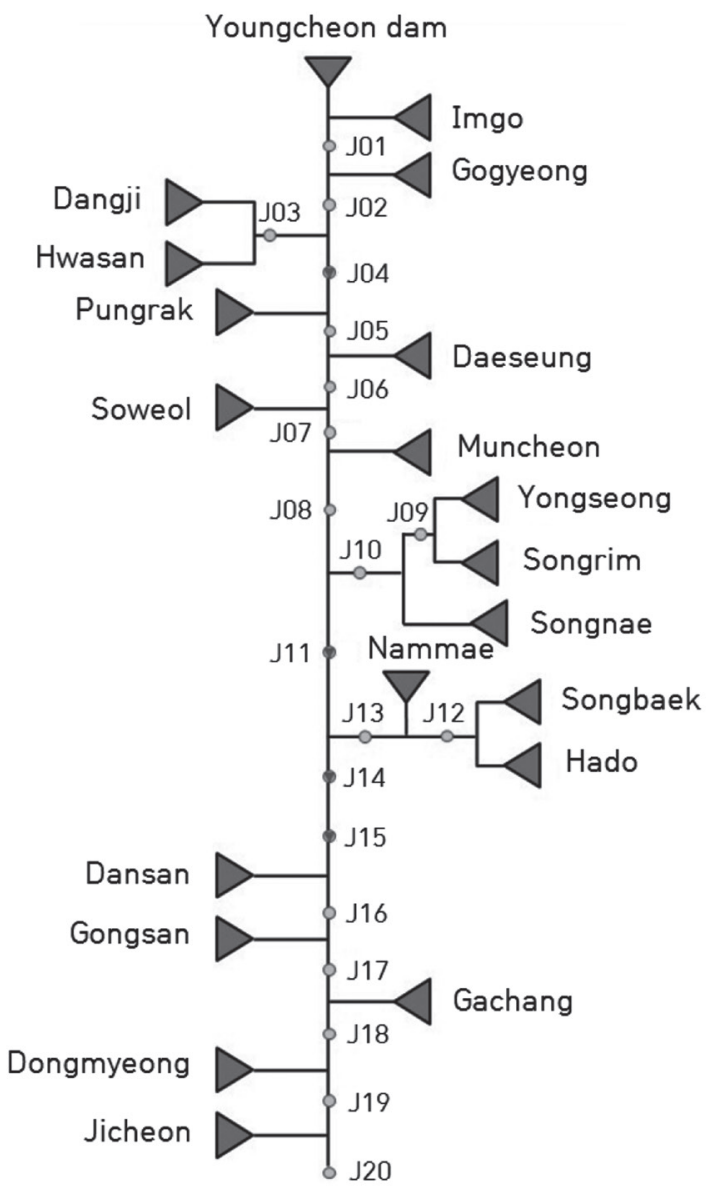

Fig. 7. Stream network of Geumho river by considering the location of reservoirs and dams.

$$
\begin{aligned}
& \mathrm{QI}_{\text {down }}(\mathrm{i})=\mathrm{SQ}_{\text {up1 }}(\mathrm{i})+\mathrm{OV}_{\text {up } 1}(\mathrm{i})+\mathrm{SQ}_{\text {up2 }}(\mathrm{i}) \\
& +\mathrm{OV}_{\text {up2 }}(\mathrm{i})+\mathrm{QL}(\mathrm{i}) \\
& \mathrm{QS}_{\text {down }}(\mathrm{i})=\mathrm{SQ}_{\text {up }}(\mathrm{i})+\mathrm{OV}_{\text {up }}(\mathrm{i})+\mathrm{QS}_{\text {up }}(\mathrm{i})+\mathrm{QL}(\mathrm{i}) \\
& \mathrm{QS}_{\text {down }}(\mathrm{i})=\mathrm{QS}_{\text {up1 }}(\mathrm{i})+\mathrm{QS}_{\mathrm{up} 2}(\mathrm{i})+\mathrm{QL}(\mathrm{i}) \\
& \mathrm{QI}_{\text {down }}(\mathrm{i})=\mathrm{SQ}_{\mathrm{up}}(\mathrm{i})+\mathrm{OV}_{\mathrm{up}}(\mathrm{i})+\mathrm{QS}_{\mathrm{up}}(\mathrm{i})+\mathrm{QL}(\mathrm{i}) \\
& \mathrm{QI}_{\text {dow }} \mathrm{n}(\mathrm{i})=\mathrm{SQ}_{\text {up }}(\mathrm{i})+\mathrm{QS}_{\text {up }}(\mathrm{i})+\mathrm{QL}(\mathrm{i}) \\
& \mathrm{S}(\mathrm{i})=\mathrm{S}(\mathrm{i}-1)+\mathrm{QI}(\mathrm{i})-\mathrm{EW}(\mathrm{i})-\mathrm{SQ}(\mathrm{i}) \\
& \mathrm{OV}(\mathrm{i})=\mathrm{S}(\mathrm{i})-\mathrm{FS} \text {, if } \mathrm{H}(\mathrm{i})>\mathrm{FH}
\end{aligned}
$$

The runoff model called DAWAST model (Noh, 2001) as shown in Fig. 9 was selected to simulate reservoir inflow and lateral flow on a daily basis, in which return flows from paddy fields (35\%) and domestic and industrial areas (65\%) were added to natural flow by DAWAST model. The DAWAST model is conceptual lumped hydrologic model with 5 parameters such as UMAX (unsaturated maximum soil depth), LMAX (saturated maximum soil depth), FC (field capacity), CP (coefficient of deep percolation), and CE (coefficient of watershed evapotranspiration).

\section{Comparing streamflows at stream junction nodes with and without considering upstream reservoir operations}

From upstream to downstream, reservoir inflows are simulated using equation (11) on a daily basis. Reservoir outflow for water supply (SQ) is paddy irrigation water and is estimated on a daily basis based on paddy water requirements composing of evapotranspiration by Penman Monteith equation, infiltration rate (here applied to $5 \mathrm{~mm} /$ day), hydraulic facility management loss rate (15\%), and cultivation management loss rate (20\%). The amount of water supplied to the paddy field is calculated by the amount of irrigated area multiplied by pond-
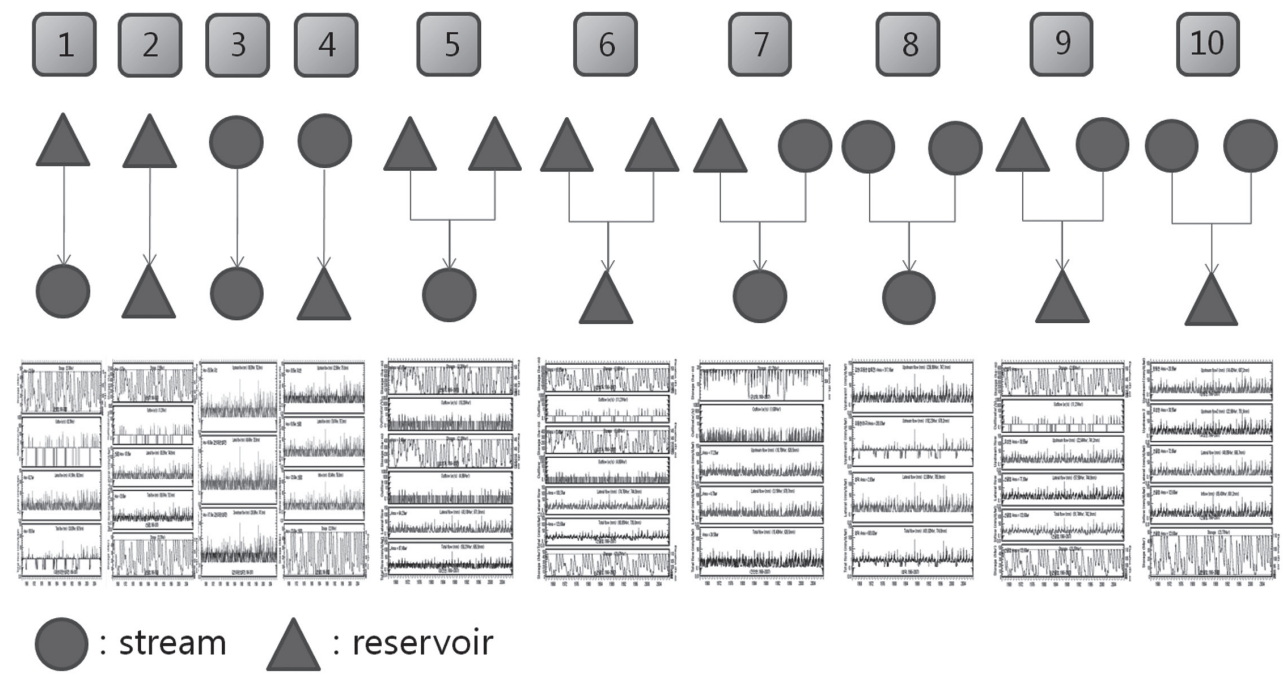

Fig. 8. Classification of stream network for stream water balancing by considering the location of reservoir. 


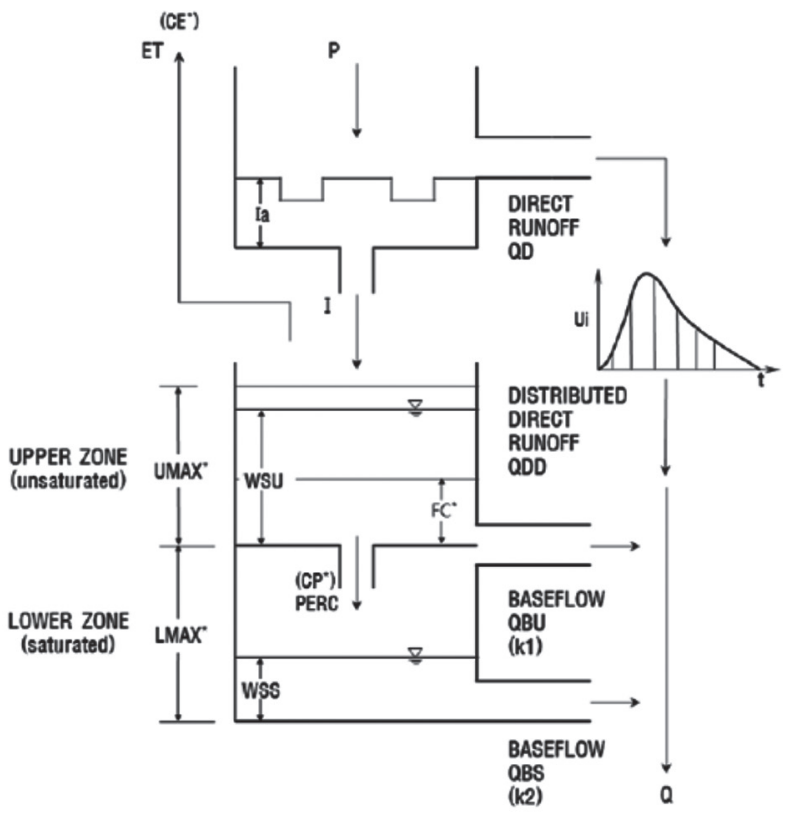

Fig. 9. chematic diagram of DAWAST model.

ing depth required in each cultivation periods (maximum $60 \mathrm{~mm}$ ). An effective rainfall is considered in calculating ponding depth. The streamflows at the junction nodes of standard hydrologic basin are simulated by considering the operation of upstream reservoirs on a daily basin. And then assuming that there are no reservoirs upstream, the streamflows at the junction nodes of standard hydrologic basin are also simulated in the same method. Using the above result, two simulated streamflows are compared by drawing flow duration curve (FDC). Streamflows at the junction nodes are simulated from 1966 to 2016 on a daily basis, annual averaged daily streamflows are sorted from high to low, and the $1^{\text {st }}, 95^{\text {th }}$, $185^{\text {th }}, 275^{\text {th }}, 355^{\text {th }}$ flows, and annual sums are compared.

\section{RESULTS}

\section{Simulating daily reservoir storages}

Using observed reservoir water storages from 1991 to 2015, parameters of DAWAST model were determined and reservoir inflows were simulated on a daily basis. And paddy water requirements to the irrigated paddy area were estimated on a daily basis. Using the above data, the reservoir water storages were simulated by equation (11). And the reservoir simulated water storages were compared with the observed through equal value line (EVL). The above process was performed on all selected reservoirs and dams within the Geumho river basin.

Fig. 10 and Fig. 12 show examples of daily reservoir simulated water storages in Dangji and Pungrak reservoirs, respectively. And Fig. 11 and Fig. 13 show examples of EVLs on Dangju and Pungrak reservoirs, respectively. The simulated result of reservoir water storages on Dangji reservoir showed annual mean rainfall $1,106.2 \mathrm{~mm} \quad\left(9.28 \mathrm{Mm}^{3}\right)$, reservoir inflow $436.6 \mathrm{~mm}$ $\left(3.66 \mathrm{Mm}^{3}\right)$, runoff ratio $39.5 \%$, water surface evapora-
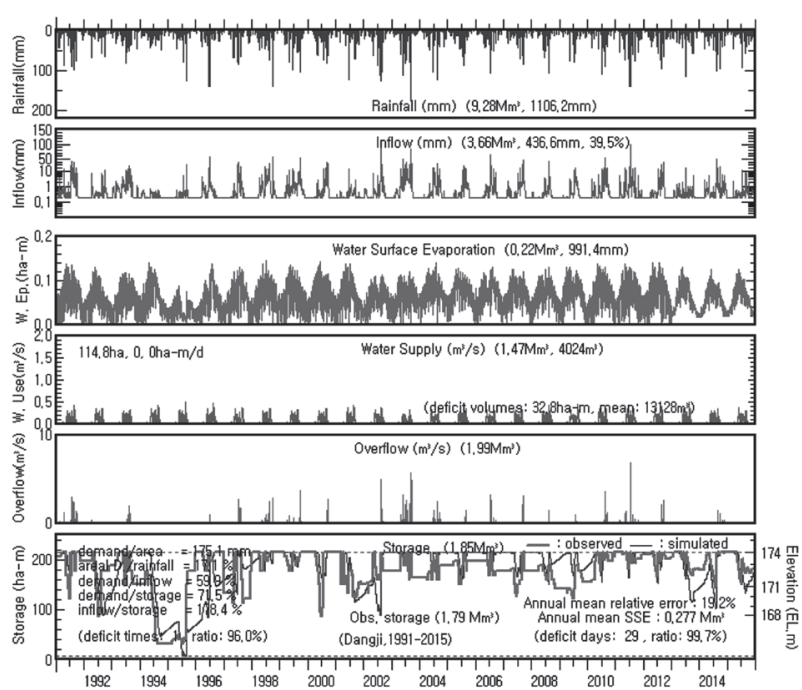

Fig. 10. Comparison of daily reservoir water storages by equation (10) (Dangji, 1991 2015).

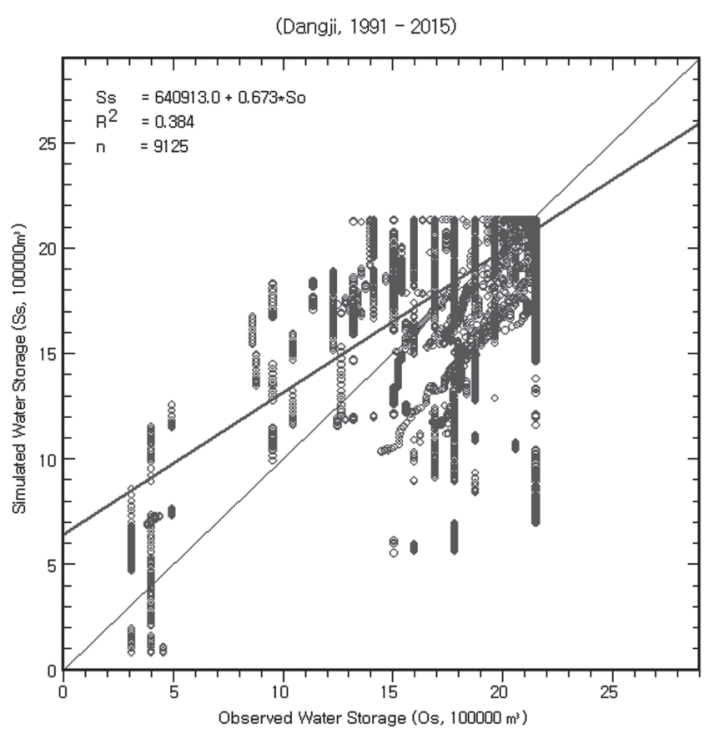

Fig. 11. Equal value line between observed and simulated daily reservoir water storage (Dangji, 1991 2015).
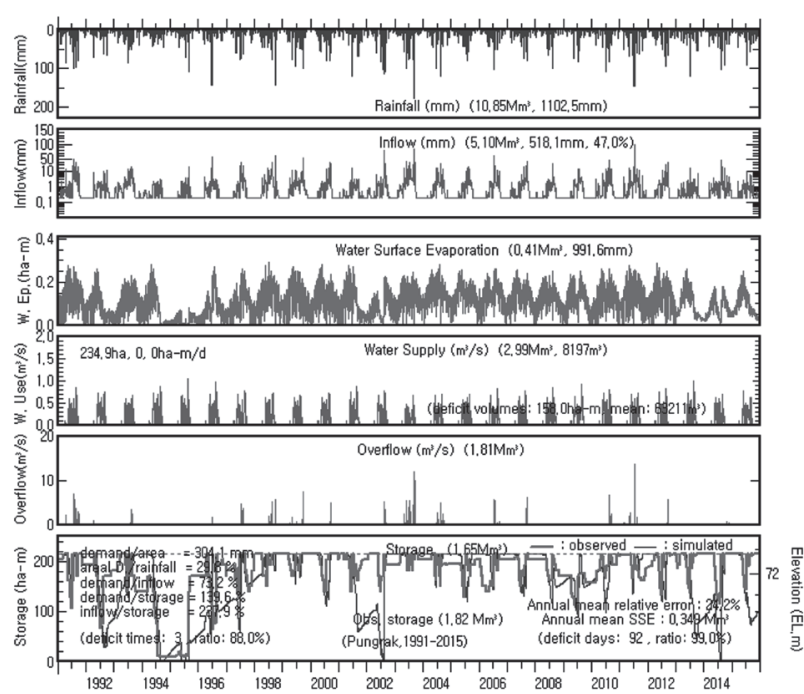

Fig. 12. Comparison of daily reservoir water storages by equation (10) (Pungrak, 1991 2015). 


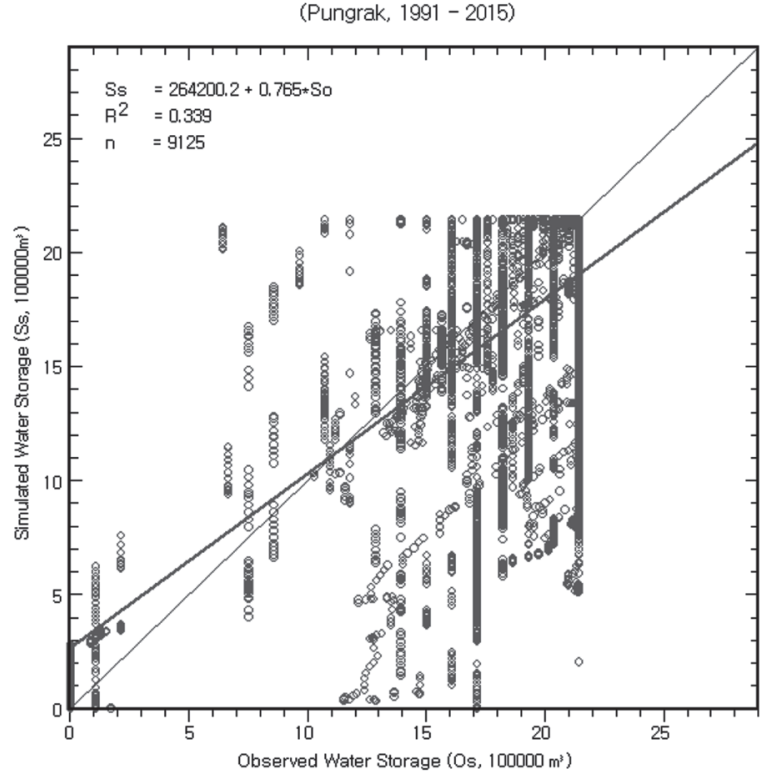

Fig. 13. Equal value line between observed and simulated daily reservoir water storage (Pungrak, 1991 2015).

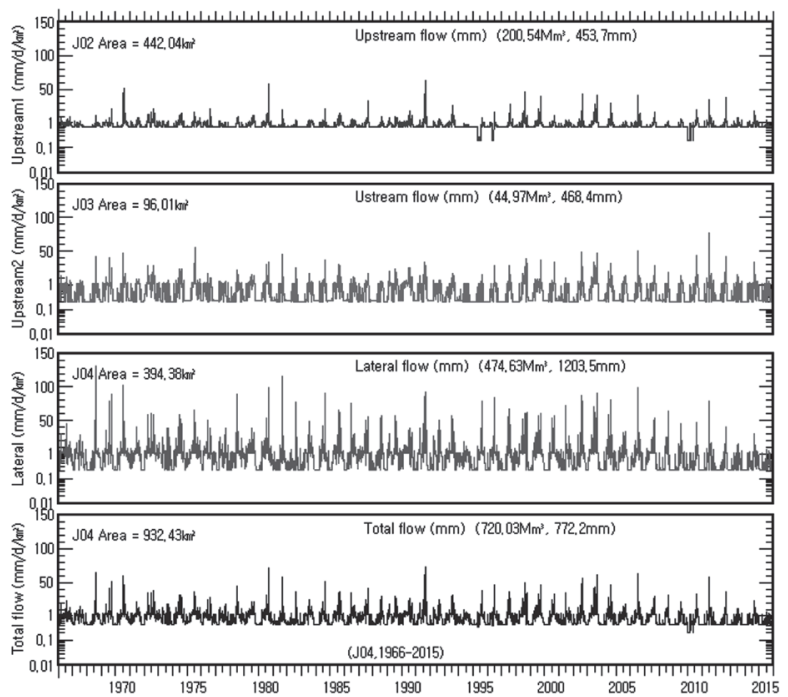

Fig. 14. Daily streamflow simulated at the junction node J04 in case considering upstream reservoir operation.

tion $0.22 \mathrm{Mm}^{3}$ (991.4 mm), supplied irrigation water $1.47 \mathrm{Mm}^{3}$ (irrigated area $114.8 \mathrm{ha}$ ), overflow $1.99 \mathrm{Mm}^{3}$, and reservoir mean water storage $1.85 \mathrm{Mm}^{3}$ (observed $1.79 \mathrm{Mm}^{3}$ ). And the result of Pungrak reservoir annual mean rainfall $1,102.5 \mathrm{~mm}\left(10.85 \mathrm{Mm}^{3}\right)$, reservoir inflow $518.1 \mathrm{~mm}\left(5.10 \mathrm{Mm}^{3}\right)$, runoff ratio $47.0 \%$, water surface evaporation $0.41 \mathrm{Mm}^{3}(991.6 \mathrm{~mm})$, supplied irrigation water $2.99 \mathrm{Mm}^{3}$ (irrigated area 234.9 ha), overflow $1.81 \mathrm{Mm}^{3}$, and reservoir mean water storage $1.65 \mathrm{Mm}^{3}$ (observed $1.82 \mathrm{Mm}^{3}$ ). Equal value lines were scattered in 45 degrees but simulated water storages were evaluated to be allowable taking into account the past occasionaly observing environment based on the eyes of observer.

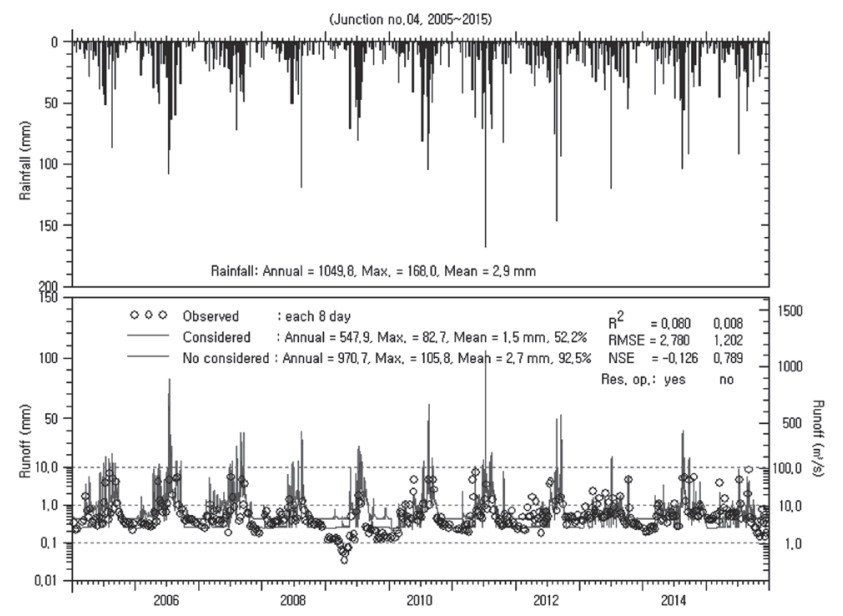

Fig. 15. Comparison of streamflows simulated at the junction node J04 in cases with and without considering upstream reservoir operation, and each 8 day observed streamflows.

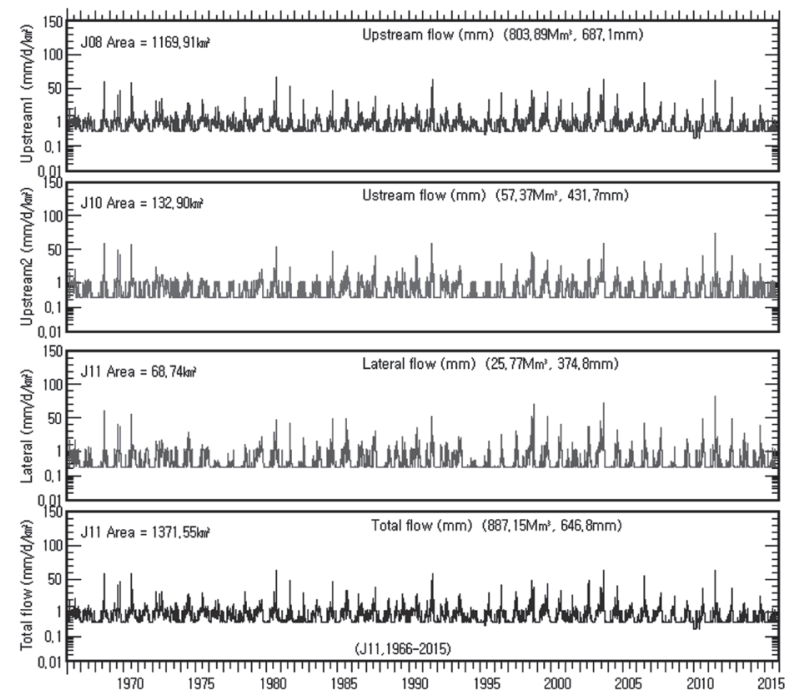

Fig. 16. Daily streamflow simulated at the junction node J11 in case considering upstream reservoir operation.

\section{Simulating streamflow at the junction nodes of} hydrologic standard basin

Streamflows at the junction nodes of each hydrologic standard basin were simulated in cases with and without considering upstream reservoir operations on a daily basis. Simulation results at the junction nodes such as J04, J11, J14, J15, and J20 with observed data were shown as examples in Fig. 14 (J04), Fig. 16 (J11), Fig. 18 (J14), Fig. 20 (J15), and Fig. 22 (J20). And simulation results were compared with each other in cases with and without considering upstream reservoir operations, and were compared with observed streamflow data. Fig. 15, Fig. 19, and Fig. 22 showed examples of comparing with each 8 day observed data. And Fig. 17 and Fig. 


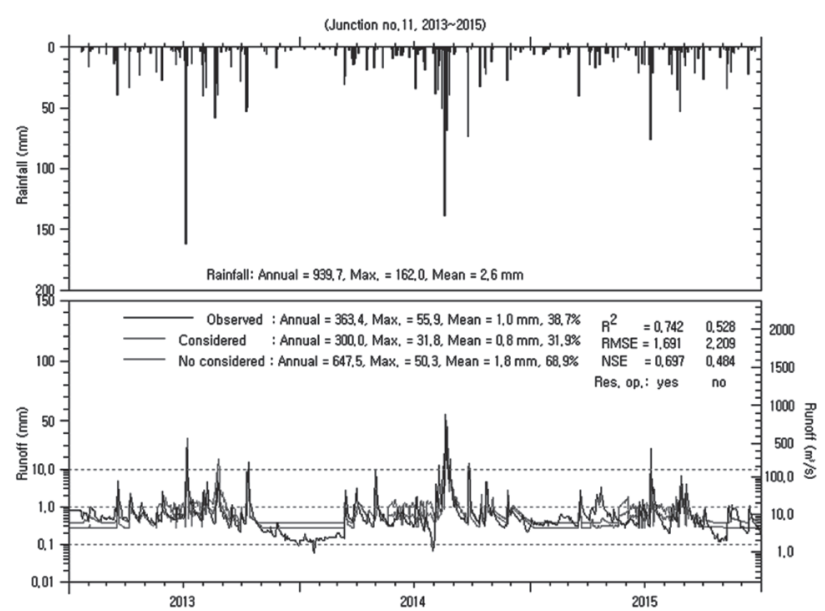

Fig. 17. Comparison of streamflows simulated at the junction node J04 in cases with and without considering upstream reservoir operation, and observed streamflows.
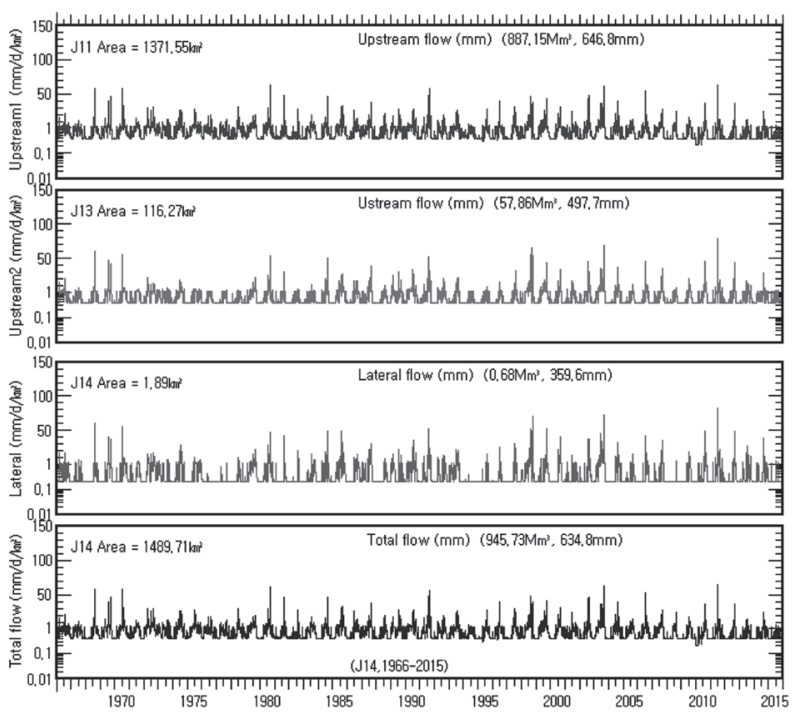

Fig. 18. Daily streamflow simulated at the junction node J14 in case considering upstream reservoir operation.

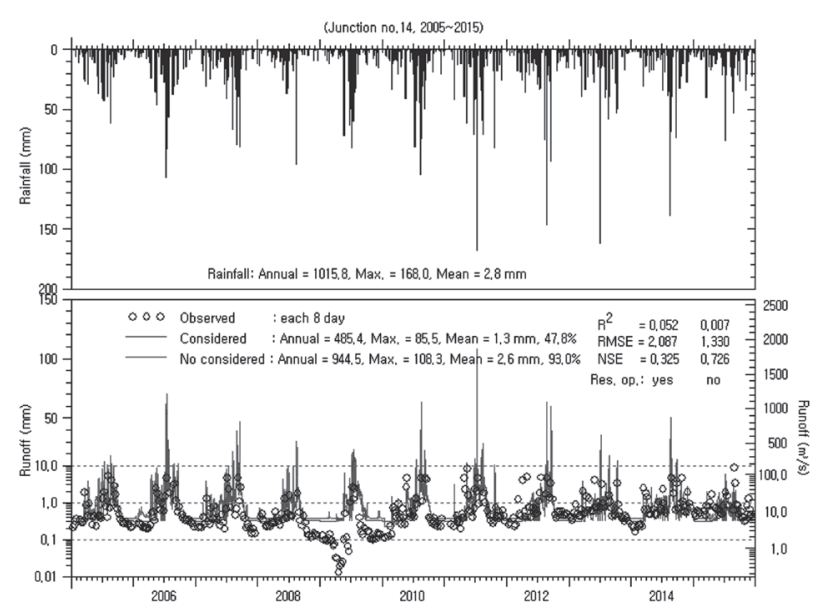

Fig. 19. Comparison of streamflows simulated at the junction node J14 in cases with and without considering upstream reservoir operation, and each 8 day observed streamflows.

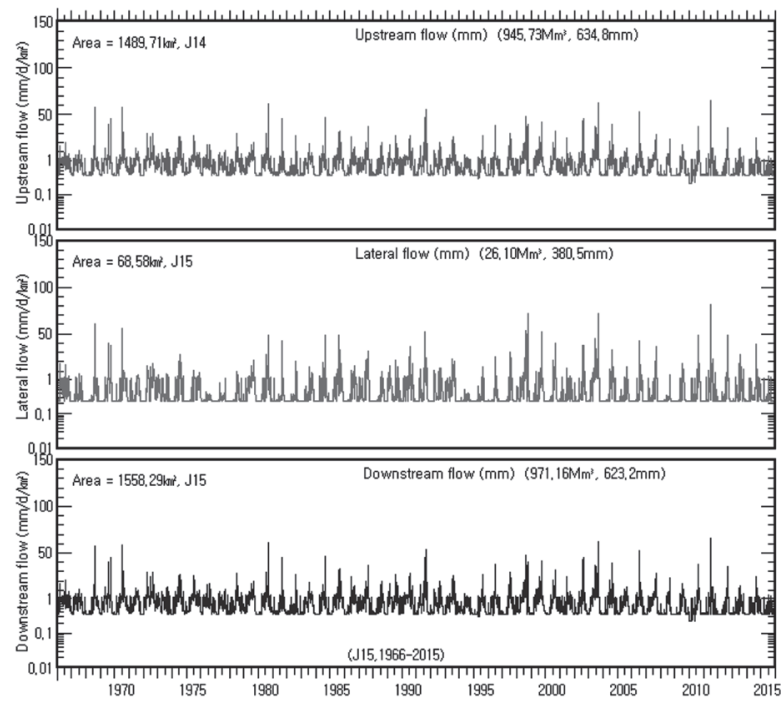

Fig. 20. Daily streamflow simulated at the junction node J15 in case considering upstream reservoir operation.

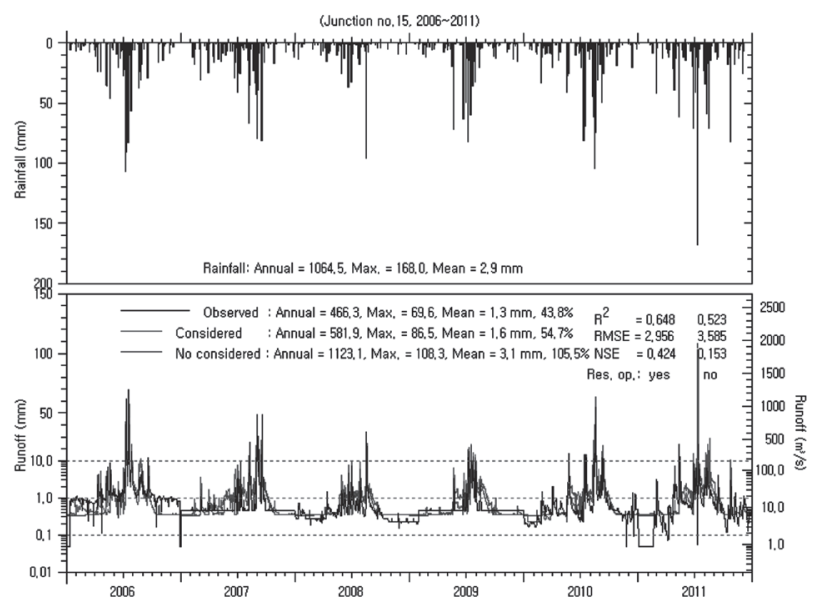

Fig. 21. Comparison of streamflows simulated at the junction node J15 in cases with and without considering upstream reservoir operation, and observed streamflows.

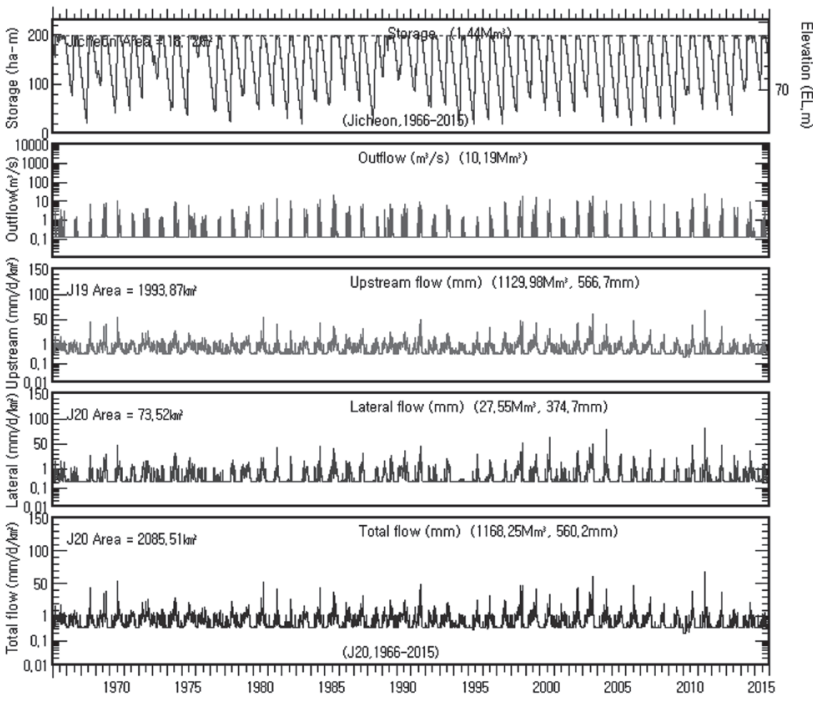

Fig. 22. Daily streamflow simulated at the junction node J20 in case considering upstream reservoir operation. 


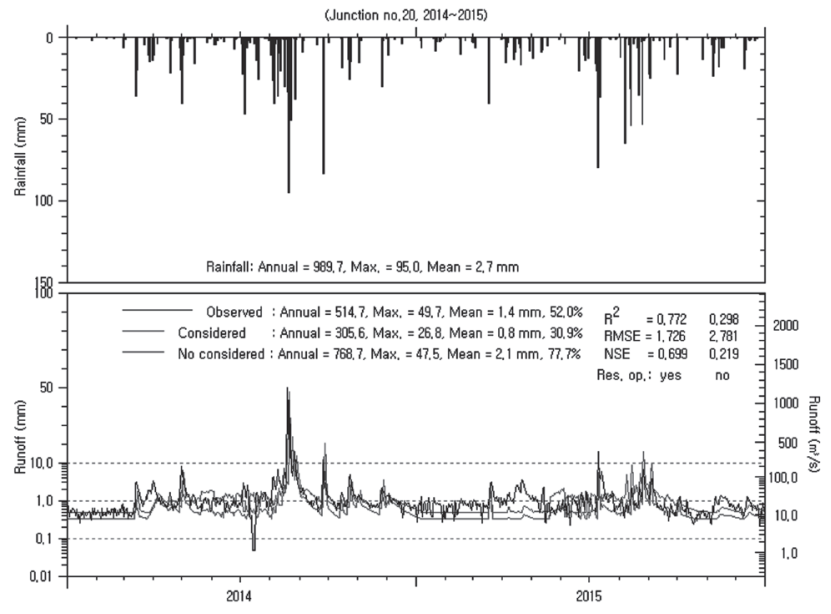

Fig. 23. Comparison of streamflows simulated at the junction node J20 in cases with and without considering upstream reservoir operation, and observed streamflows.

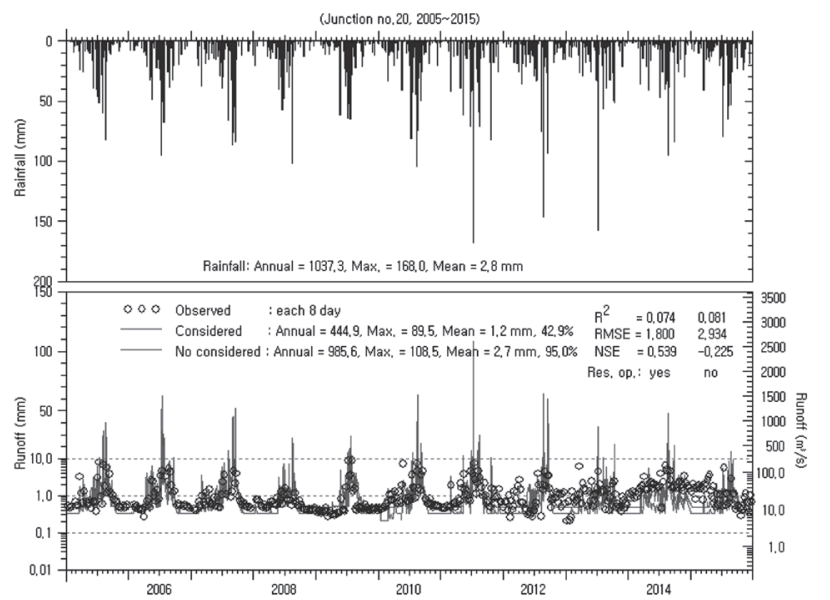

Fig. 24. Comparison of streamflows simulated at the junction node J20 in cases with and without considering upstream reservoir operation, and each 8 day observed streamflow.

Table 3. The results of flow duration analyses in the junction nodes of hydrologic standard basin with and without considering the upstream reservoir operations

\begin{tabular}{|c|c|c|c|c|c|c|c|c|c|c|c|c|}
\hline \multirow{2}{*}{$\begin{array}{l}\text { Junction } \\
\text { no. }\end{array}$} & \multicolumn{2}{|c|}{$\begin{array}{l}\text { 1st flow } \\
\text { (mm) }\end{array}$} & \multicolumn{2}{|c|}{$\begin{array}{l}\text { 95th flow } \\
\text { (mm) }\end{array}$} & \multicolumn{2}{|c|}{$\begin{array}{l}\text { 185th flow } \\
\text { (mm) }\end{array}$} & \multicolumn{2}{|c|}{$\begin{array}{l}275 \text { th flow } \\
\text { (mm) }\end{array}$} & \multicolumn{2}{|c|}{$\begin{array}{c}\text { 355th flow } \\
\text { (mm) }\end{array}$} & \multicolumn{2}{|c|}{$\begin{array}{l}\text { Annual flow } \\
\text { (mm) }\end{array}$} \\
\hline & yes & no & yes & no & yes & no & yes & no & yes & no & yes & no \\
\hline J01 & 24.12 & 32.58 & 0.98 & 0.81 & 0.88 & 0.35 & 0.86 & 0.23 & 0.82 & 0.22 & 479.5 & 427.6 \\
\hline J02 & 24.64 & 32.62 & 0.89 & 0.89 & 0.73 & 0.38 & 0.69 & 0.25 & 0.66 & 0.24 & 453.5 & 434.0 \\
\hline J03 & 34.52 & 38.83 & 1.13 & 1.28 & 0.39 & 0.43 & 0.23 & 0.25 & 0.21 & 0.24 & 468.3 & 514.6 \\
\hline J04 & 47.31 & 32.75 & 1.32 & 0.90 & 0.74 & 0.37 & 0.51 & 0.26 & 0.44 & 0.24 & 772.2 & 431.9 \\
\hline J05 & 46.94 & 32.76 & 1.31 & 0.92 & 0.73 & 0.38 & 0.50 & 0.26 & 0.44 & 0.25 & 766.0 & 435.9 \\
\hline J06 & 45.79 & 39.19 & 1.26 & 0.94 & 0.70 & 0.38 & 0.48 & 0.26 & 0.42 & 0.25 & 739.9 & 439.9 \\
\hline J07 & 44.50 & 41.26 & 1.20 & 1.02 & 0.67 & 0.40 & 0.46 & 0.26 & 0.40 & 0.25 & 704.1 & 469.5 \\
\hline J08 & 43.80 & 41.27 & 1.17 & 1.07 & 0.65 & 0.41 & 0.45 & 0.27 & 0.39 & 0.26 & 687.1 & 477.5 \\
\hline J09 & 27.65 & 38.22 & 0.65 & 0.89 & 0.29 & 0.35 & 0.20 & 0.23 & 0.20 & 0.22 & 344.5 & 434.1 \\
\hline J10 & 32.66 & 38.39 & 0.97 & 1.31 & 0.39 & 0.46 & 0.26 & 0.30 & 0.25 & 0.28 & 431.5 & 507.5 \\
\hline J11 & 41.67 & 38.12 & 1.13 & 1.07 & 0.62 & 0.41 & 0.42 & 0.28 & 0.37 & 0.28 & 646.9 & 458.6 \\
\hline J12 & 34.92 & 38.49 & 0.95 & 1.01 & 0.36 & 0.39 & 0.24 & 0.25 & 0.22 & 0.24 & 439.0 & 471.1 \\
\hline J13 & 36.09 & 39.34 & 1.08 & 1.73 & 0.52 & 0.89 & 0.39 & 0.73 & 0.36 & 0.69 & 497.2 & 678.2 \\
\hline J14 & 40.63 & 38.16 & 1.13 & 1.12 & 0.62 & 0.45 & 0.42 & 0.32 & 0.37 & 0.31 & 634.9 & 473.1 \\
\hline J15 & 40.32 & 38.20 & 1.11 & 1.17 & 0.61 & 0.48 & 0.41 & 0.36 & 0.36 & 0.34 & 623.1 & 489.6 \\
\hline J16 & 40.13 & 40.02 & 1.10 & 1.19 & 0.60 & 0.48 & 0.41 & 0.37 & 0.36 & 0.35 & 618.8 & 496.2 \\
\hline J17 & 39.25 & 38.63 & 1.07 & 1.27 & 0.58 & 0.53 & 0.39 & 0.41 & 0.34 & 0.40 & 598.9 & 519.2 \\
\hline J18 & 38.19 & 40.61 & 1.03 & 1.33 & 0.55 & 0.61 & 0.37 & 0.46 & 0.33 & 0.44 & 578.3 & 566.3 \\
\hline J19 & 37.68 & 39.21 & 1.00 & 1.33 & 0.54 & 0.62 & 0.37 & 0.50 & 0.33 & 0.48 & 566.7 & 554.9 \\
\hline J20 & 37.39 & 37.76 & 0.99 & 1.35 & 0.54 & 0.61 & 0.37 & 0.49 & 0.33 & 0.47 & 560.1 & 549.0 \\
\hline
\end{tabular}

21 showed examples of comparing with daily observed data. The simulation results in case with considering upstream reservoir operation were better than that in case without considering reservoir in determination coefficient $\left(\mathrm{R}^{2}\right)$, root mean square error (RMSE), and NashSchcliffe model efficiency (NSE) without the result in Fig. 15.

\section{Flow duration analysis}

Using the above simulated streamflow results at the junction nodes of hydrologic standard basin within
Geumho river basin in cases with and without considering upstream reservoir operations, flow duration curves were derived and compared each other as shown in Table 3. FDCs at major junction nodes were shown in Fig. 25. From the above flow duration analyses at the junction nodes, it was concluded that the amount of streamflow was affected from the upstream reservoir operations in more or less according to the reservoir capacity, and its effects were decreased less along the river reach downstream. Youngcheon dam with high water storage capacity of $81 \mathrm{Mm}^{3}$ had a great influence 

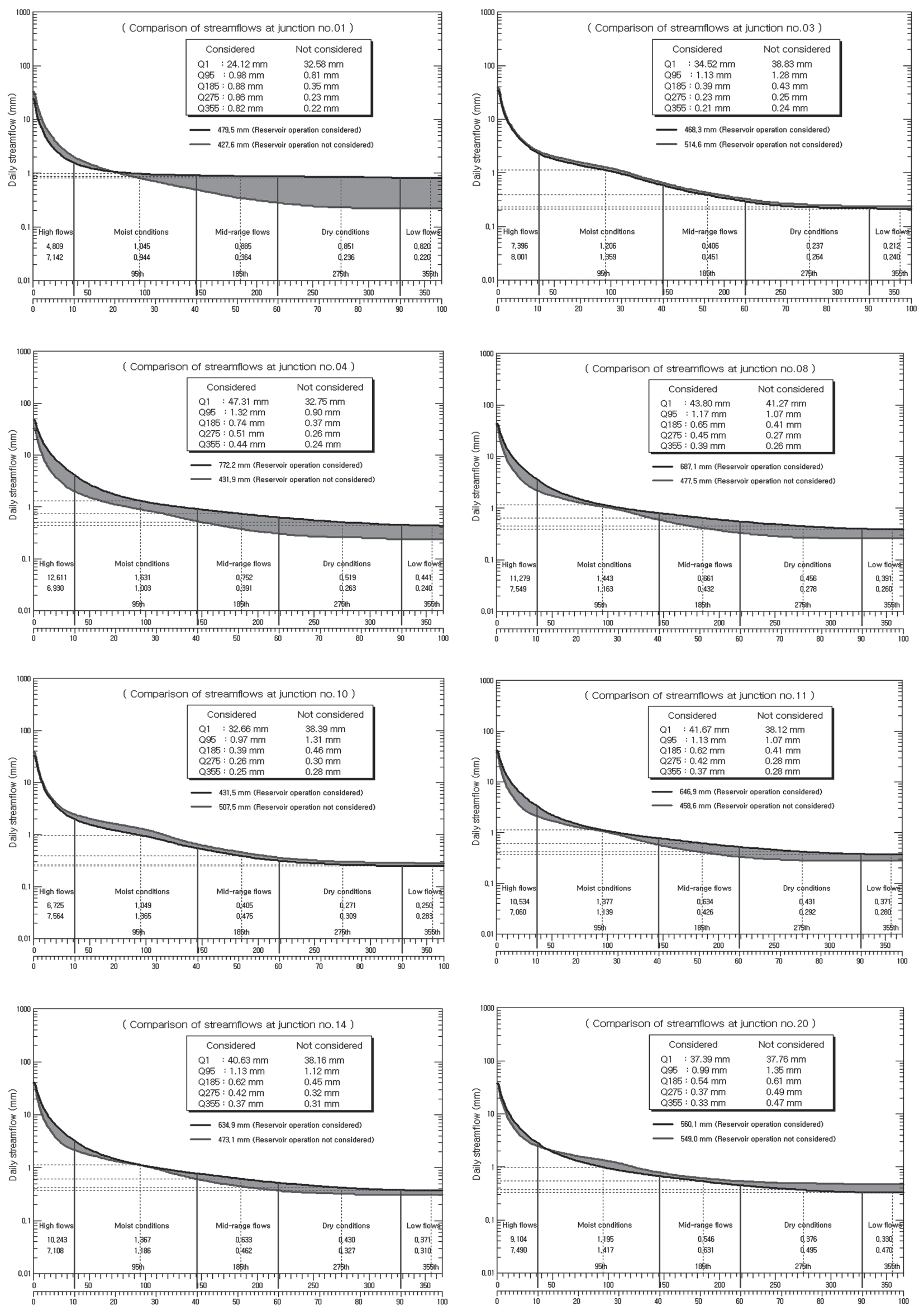

Fig. 25. Comparison of flow duration curves at major junction nodes of hydrologic standard basin in cases with and without upstream reservoir operations 
on the downstream stream flow amount according to reservoir operation from the result of junction node, J01. But the amount of streamflows was more affected from the return flows in the domestic and industrial areas within the watershed.

\section{DISCUSSION}

To verify the possibility of modeling streamflows by hydrologic standard basin considering the upstream agricultural reservoir operation, the Geumho river basin watershed area of $2,092 \mathrm{~km}^{2}$ with 18 agricultural reservoirs with over $1 \mathrm{Mm}^{3}$ was selected to test watershed. And 2 dams are located within the basin to supply domestic water, and one multipurpose dam. Hydrologic standard basin was separated into 20 basins which located one or two reservoirs, or have no reservoirs. Stream network was constructed, and the water balance equations at the junction nodes in hydrologic standard basin were composed of 10 cases for simulating daily streamflows considering stream network. The amount of streamflows was simulated on a daily basis in cases with and without upstream reservoir operations. FDCs were drawn and compared with each other. The results obtained are as follows;

First, the streamflows considering upstream reservoir operations were better simulated than that in case of no considering upstream reservoirs.

Second, the amount of streamflow in hydrologic standard basin with large water storage reservoir affected more than that with small water storage reservoir.

Third, return flows from urban areas with many population showed to the amount of stream flows to a great extent

\section{AUTHOR CONTRIBUTIONS}

Jaekyoung NOH carried out substantial contribution to the concept and design on this paper. Jaenam LEE supervised the project, analyzed the data and wrote the paper. Yoshiyuki SHINOGI commented the possibility to apply to the Japanese watershed. Taek-Keun OH carried out analysis and interpretation of data. All authors commented on the manuscript.

\section{ACKNOWLEDGMENT}

This work was supported by research fund of Chungnam National University, Republic of Korea.

\section{REFERENCES}

Choi, N. W. 2010 The Plan for Instream Flow Security by Agricultural Reservoir. M. S. thesis, Yongnam Univ., Gyeongsan, Korea [in Korean]

Jee, Y. K., M. S. Lee, J. H. Lee and J. H. Jang 2012 Analysis of water quality improvement in downstream river of heightening irrigation dam through the reservoir operation. J. Korea Water Resources Association, 45: 929-941 [in Korean]

Kim, N. W. and J. E. Lee 2009 Assessment of probability flood according to the flow regulation by multi-purpose dams in Han-River Basin. J. Korea Water Resources Association, 42: 161-169 [in Korean]

Kim, S. H. 2007 A Study on the Water Management of Youngsan River. M. S. thesis, Chonnam Univ., Gwangju, Korea [in Korean]

Kim, T. G., Y. N. Yoon and J. H. Ahn 2002 An analysis on the changes of flow duration characteristics due to dam construction. J. Korea Water Resources Association, 35: 807-816 [in Korean]

Ko, K. G. 2015 An Effectiveness Analysis of Improving Water Quality by Management of Instream Flow and Water Quality of Dams. Ph. D. dissertation, Chonnam National Univ., Gwangju, Korea [in Korean]

Lee, J. N. and Y. J. Kim 2011 Analysis of flow duration characteristics due to environmental change in Korea River Basin. J. Korea Society of Hazard, 11(1): 105-112 [in Korean]

Lee, J. and J. Noh 2015 Evaluating water supply capacity of embankment raised reservoir on climate change. J. Korean Society Agri. Engineers, 57: 73-84 [in Korean]

MOLIT (Ministry of Land, Infrastructure and Transport) 2009 Estimation, Calculation and Securing of Instreamflow by Basin Considering Improvement of Natural and Social Environment [in Korean]

MOLIT (Ministry of Land, Infrastructure and Transport) 2010 Improvement of Standard of Water Hydrologic Map according to 4 River Restoration Project [in Korean]

Mwamila, T. B., R. J., Kimwaga and F. W. Mtalo 2008 Eco-hydrology of the Pangani river downstream of Nyumba ya Mungu reservoir, Tanzania. Physics and Chemistry of the Earth, 33: $695-700$

Noh, J. 1991 A Conceptual Watershed Model for Daily Streamflow Based on Soil Water Storage. Ph. D. Dissertation, Seoul National University, Seoul, Korea, 183 pp. [in Korean]

Noh, J. and J. Lee 2011 Comparison of streamflow runoff model in Korea for applying to reservoir operation. CNU J. Agri. Sci., 38(3): 513-514 [in Korean]

Shin, H. S., D. K, Kang and S. D. Kim 2007 Analysis of the effect of water budget elements on flow duration characteristics using SWAT-Nak Dong. J. Korea Water Resources Association, 43: 251-263 [in Korean]

Wellmeyer, J. L., M. C. Slattery, and J. D. Phillips 2005 Quantifying downstream impacts of impoundment on flow regime and channel planform, Lower Trinity river, Texas. Geomorphology, 69: 1-13

Yeo, H. J. 2012 The Plan for Instream Flow Security by Agricultural Reservoir. M. S. thesis, Sekyeong Univ., Seoul, Korea [in Korean] 